\title{
The Paradigm of Value Ideology of Pancasila as the Basis of Citizenship Education in the Global Perspective
}

\author{
Suwarma Al Muchtar*, Dede Iswandi \\ Department of Civic Education \\ Universitas Pendidikan Indonesia \\ Bandung, Indonesia \\ *suwarma@gmaill.com
}

\begin{abstract}
Negative influences of globalization has eroded the values of Pancasila Ideology as the nation identity and becoming a serious problem in Indonesia. This research aims to examine and describe the values the philosophy of Pancasila as the core of citizenship education in accordance with a global perspective. This study used a qualitative approach using the study of literature. Data collection was done through the study of documentation and library studies, while data analysis is done through the presentation of data, data reduction and withdrawal of the conclusion. The results showed that the Pancasila philosophy based on the paradigm of values contained therein, namely the value of customs, socio-cultural nation of Indonesia which is the identity of the nation of Indonesia should be the core content of educational charge Citizenship in Indonesia because it could have implications for the normative value of the practice of the Constitution in daily life and will be able to become a factor of filtration against negative influences of globalization. This became the core of the strengthening of civic education in the development of citizens who have a goal to realize the good citizens and smart.
\end{abstract}

Keywords - the value of the ideology of pancasila; civic education

\section{INTRODUCTION}

Nowadays, the phenomena of empirical facts and negative influences of globalization in Indonesia such as moral decadence is becoming a serious problem which must be immediately dealt with massive and sustained. Globalization has brought social and cultural changes very quickly and touch system change value, thereby affecting the socio-cultural issues. The complexity of social issues getting stronger towards the turbulence situation. Socio-cultural changes caused by the revolution of globalization has brought the community to be able to face those changes as part of a citizen of the world [1].

In the era of reforms Indonesia experienced the challenges and nationally crush and globally from a variety of familiar in the world such as neo-liberalism, neo-capitalism, neoimperialism and neo-communism. When the people of Indonesia as human beings and as Nations do not face these challenges with a spirit of national insight that imbued the philosophy of life (my Weltanschauung) philosophy of
Pancasila that theism religious-identity nation of Indonesia will the difficulty of addressing challenges and ideology crush. The euphoria of reform that adore freedom, including the freedom "berideologi", then surely the people of Indonesia are unconsciously headed degradation and collapse as a nation with national ideology of Pancasila. The challenge, among others, in the form of a national challenge (internal) and international (external), especially the process of degradation of national insight as the impact of globalization- liberalization; the dynamics of modernization that was further struck the man as part of postmodernism, the tendency of Revere freedom for the sake of freedom; the cult of individualism in the name of HUMAN RIGHTS based on the principle of liberalism, not based on a system of philosophy and the view of her life (my Weltanschauung) as the nation and the State. As a result most citizens will be affected and implicates to occurrence of erosion of ideology; the dynamics of globalization- liberalization [2]. Because of the freedom, rights and individual human rationality is recognized when these individuals are members of the political community [3].

The emergence of the ideology of the Neo in the era of globalization is affecting implementation and the ideological purity of theology developing countries, affects the implementation and also on the ability of the citizens of Indonesia actualize the ideology of Pancasila. Civics and Citizenship Education citizenship in Indonesia as faced with the challenge to strengthen core citizenship education in addressing the challenges of overcoming the negative influences of globalization especially related global challenges and ideology crush. This is because the civic education has a sacred mission with idealism to the intellectual life of the nation based on the character and civilization to the establishment of the nation to be democratic, human and responsible both socio-political philosophy, and psychopedagogical [4].

Wahab States that in the new nationality must understand actualize by practicing the values of Pancasila which had been almost forgotten as both a philosophical basis, and the State ideology [5]. Without practice the values of Pancasila in actualize new nationality that understand the problems faced now (in Indonesia as one of the great nation) if without the 
philosophical and ideological base, then almost it is certain to fail in the nation-building efforts. Therefore necessary to build Civics education ideology of Pancasila as the value based on the Constitution of the year 1945 in a Global perspective.

In an effort to understand the direction of citizenship education as a values education and character of Pancasila with regard to socio-cultural values change accelerated with the information and communication technology, the development paradigm and approach in the science of social science. This study proposes a paradigm science citizenship upon the philosophy of Pancasila. This aims to enhance citizenship education as ideology Pancasila values, education in the information retrieval of the actual problems, using information and communication technology appropriately in accordance with the purpose of establishing the country faithful, devoted to God Almighty and noble character.

\section{METHOD}

This study used a qualitative approach through the method of the study of literature. This method is based on the study of literature such as books and journals. This research attempts to examine and describe the characteristics of the values of Pancasila philosophy charge in the development of citizenship education as the basis for revitalizing the global in perspective. Data collection was done through the study of documentation and library studies, whereas the data validation is performed by using the data source and the method of triangulation. Analysis of data refers to the data reduction steps, the presentation of the data and conclusions of withdrawal [6].

\section{RESULT}

Pancasila is the basis of the prevailing state of Indonesia since year 1945 based on the agreement of the nation of Indonesia [7]. As the Foundation of philosophy and ideology, Pancasila is the source of all the sources of law in the country of Indonesia. Pancasila is the fruit of the country's founders thought results that raised customs values, social values of Indonesian culture and formulated conversationally consensus based on the lofty moral in the siding of the councils and the PPKI BPUPKI finally on August 18, 1945 declared legitimate by the philosophic PPKI as Republic of Indonesia. In causality Pancasila before passed the Foundation philosophy of the State, its values has been there and is derived from the nation of Indonesia itself in the form of values, cultural mores and religious values [8]. This shows that the Pancasila values is a set of customs, socio-cultural values and religious values of the nation which Indonesia crystallized Pancasila which reflects the characteristics of the nation of Indonesia.

Pancasila consists of five sila (principle). These principles reflect the identity of the nation of Indonesia as a hallmark of Indonesia national character and which includes:

1. The first principle is a belief in one Supreme beings (Sila divinity of the one true God). This principle has a payload value of Godhead, that Indonesia is a State religion and godliness and is not a secular State;

2. The second Principle are described as commitments internationally or in more literal toward humanity principle upheld the fulfillment and protection of human rights in a fair and civilized Humanity Sila (a fair and Civilised). Commitment to a just and civilized humanity requires a willingness to treat others well, even strangers, in a manner that is fair, free from suspicion, exploitation, and oppression. This is a form of the fulfillment and protection of human rights;

3. The third Sila stated commitment to Indonesia's unity (Unity Sila Indonesia). Indonesia is an archipelago which has a vast archipelago that stretches approximately 5,000 kilo meters away across the sea, with 13,000 islands and approximately 350 different ethnic groups, therefore this principle emphasizes the unity of the country;

4. The fourth Sila emphasizes the idea of people who led or governed by a wise policy through a process of consultation and consensus (Sila Populist led by Wisdom in Consultative/representative). Word of deliberation is a connotation of discussions and deliberations among members of the public, but does not show ideas such as the powers of the majority and minority rights, but rather to put forward to the principle of tolerance and mutual valuing with the orientation of a consensus decision based on wisely for the benefit of the public.

5. The fifth Sila stated commitment to social justice for all the people of Indonesia (Sila of social justice for all the people of Indonesia). This principle is upheld the commitment to create a social welfare for all the people of Indonesia, not the welfare of the individual as well as the welfare of the group but the welfare of the whole people of Indonesia.

Mansyur explain that to the people of Indonesia, Pancasila has the functions and role of the assortment are [9]:

1. The Pancasila as the nation's view of life. Meaning of Pancasila is a series of great value, which is thoroughly against life itself that serves as a frame of reference both to organize the life of personal self and interact between human beings in society and nature the surroundings. Pancasila is the crystallization of values that live in the community and Indonesia is rooted in the culture of the nation, it will be a high esteem by its citizens. The peak of Pancasila is moral ideals that give guidelines and spiritual power to the people of Indonesia in the life of society, nation and State. Pancasila is the basis of view destination nation Indonesia will be achieved and it will be a view of life that is able to perceive and solve all the problems facing it appropriately, so it can deal with the issue properly.

2. Basic Pancasila as the Republic of Indonesia. Pancasila in this position is often referred to as the basic philosophy or the philosophy of basic State (Philosohische Gronslas) from the country, the ideology of the country (staatsidee). In this sense the Pancasila is a basic values and norms to regulate the governance of the country/organization of the country. Consequently the whole implementation and organization of the State especially any State legislation spelled out and derivation of the values of Pancasila. Therefore the Pancasila is the source of all sources of law. 
3. The State ideology Pancasila and the nation of Indonesia. For the nation's ideology Pancasila Indonesia substantially lifted from the view of Indonesia's own community, so that the nation of Indonesia is causa materialist (original material) Pancasila. Ideology is the teaching/doctrine/theory is believed to be the truth, arranged in systematic way, and given the hint implementation in responding to and resolving the problems encountered in the society, nation and State.

Pancasila as the ideology of the open. Pancasila as the ideology is not rigid and closed but are open, actual, dynamic, anticipatory and always able to adjust with the times, science and technology as well as the dynamics of the development of the community. The Pancasila ideology of openness does not mean changing the fundamental values embodied in it, but explicit his insights in a more concrete, so it has the ability of sharper to solve new problems and the actual constantly evolving in line with the demands of the times.

\section{DISCUSSION}

Pancasila which is rooted in the life of the nation of Indonesia in fact contains views that give priority to harmony in people's lives. Harmony could be interpreted here in the absence of the centrality to the importance of individualism but also there is no negation or counteraction of individuals in public life. Based on the consensus that Pancasila was accepted and used as the basis of the country then it should be the consistency of efforts and the presence of the leaders of the country to make the values of Pancasila as the reality in the life of nation and State. However, if there is no serious effort and consistency, whatever form the basis of the State of a nation used a country will not be worth nothing without implementation and followed up with practice in earnest in the life and State, either by the people or by the organizer of the State [7].

The consistency of effort and one of them is implemented through civics and citizenship or globally known for civic education. Citizenship education in Indonesia was cast as a means in internalize the values of Pancasila to learners who performed early on. This is because the civic education has a mission as 1) legal education that is instrumental in developing awareness of the law and capable of realizing the rights and obligations as well as have adherence to the law; 2) political education in developing political literacy, political awareness, political participation; 3 ) and educational values that play a role in transform of values, morals and norms that are considered good and in accordance with the characteristics and identity of the nation of Indonesia so that it can support the efforts of nation and character building [10].

Pancasila is seen as the country that best suits the conditions and Indonesia's political development [7]. Pancasila is often regarded as the National Guard to ensure that every citizen in Indonesia regardless of their background will be treated the same. The values of Pancasila is then translated into the official national motto, Bhineka Tunggal Ika, literally meaning Unity in diversity [11]. Pancasila which includes national cultural values have a unitary State such as 'the moral basis of the State and the nation of Indonesia' [12]. Many have noticed that regardless of all the values inherent in the Pancasila, Pancasila can be a form of control [13]. This is in line with the five pillars of the philosophy of Pancasila, which is designed to bring together 300 ethnic groups in the country, this immense archipelago. They include the belief in one God, the humanity, the unity of Indonesia, democracy, social justice and the consultative [14].

The position of Pancasila as the basic countries Indonesia different level with the position and function of ideology, Pancasila as a unifying tool or function and position of Pancasila in the life of a nation and a country more. Without the position and role of Pancasila as the basic functions of the State and the position of Pancasila in the guidelines state that other life would not be performed [7]. Therefore in the field of law Pancasila as long as it is placed as the source of all the sources of law in Indonesia. Then in the reality of life and State of each policy and Government action should be based upon the values of Pancasila. In support of this ideological intelligence of Pancasila is required to deal with the threat of a foreign ideology influence on comprehension of Pancasila State ideology as the basis for and. This is a challenge and a threat that must be faced by the nation of Indonesia in the current era of globalization.

All ideologies that are incompatible with the principles of the glorious ' Oneness of God ' such as atheism, communism, Marxism, secularism and liberalism should be banned in Indonesia. Likewise, any deeds and behaviour against the noble principles such as vice, murder, theft, rape, corruption, witchcraft, gambling, etc. should also be prohibited [15]. This is because the State ideology in fact is the basis of spirituality, is the source of the ideals, values and expectations of the norms that are considered good, so in fact Pancasila ideology as a aims to manifest prosperity life for the people of Indonesia.

Pancasila ideology as it is the most important part of the function and position of Pancasila in the life of nation and State, due to the perceived need to find intersection in order to equalize and harmonize orientation, perception, and appreciation ideology Pancasila against in various areas of life. According to Alex ideological concept contains several dimensions, including the following: 1) reflection of the reality that is life in society which appeared for the first time or at least at the beginning of his birth. This means that the ideology is an overview of the extent to which a society is able to understand the ideology; 2) dimension of idealism which abilities that submitted a painting of hope to a variety of existing groups in the community to have a life together in a better and brighter future; 3 ) dimensions of flexibility painting ability to influence and to adjust to the growth or development of communities [7].

Based on the description, then in the face of various challenges and threats of Pancasila has an important role in warding off and faced various challenges and threats that are potentially damaging and destroying the country. Pancasila ideology as a living dynamic open already should not willed it, because it is a form of challenge against the nature and identity of the nation which crystallized Pancasila of Indonesia [7]. Then open the Pancasila ideology as can overcome various challenges and threats that threaten the sustainability of the 
country and Indonesia can adjust with the times because of its open nature, actual, dynamic and anticipatory.

In addition to having the function as the legal and political ideology, Pancasila has also a function of philosophy. The content of the philosophy of Pancasila could be seen with thoughts that exist in the principles of Pancasila. Even the content of thinking in the sila-sila has a broad substance through a variety of means and includes the conduct of community life [7]. The function of the philosophy of Pancasila is the fruit according to Notonagoro musings are in, the results of the investigation and thinking deeply and thoroughly the above as well as the knowledge base and extensive experience because it's that philosophy can answer the questions as to whether the principles underlying facts?; What can I know?; whether from principles of life; philosophy often so human in setting guidelines for the attitude to life and the vagaries of the Act [16].

Through practice and implementation of Pancasila in a serious and consistent in the life of nation and State in Indonesia, it will be always oriented to the fulfillment and protection of humanitarian principles and human rights. In addition, there will always be political systems democratic included freedom of the press and other freedoms though with always pay attention to the public interest [7]. Then it takes an education that can be transmit the values of Pancasila to the next generation of the nation in an effort to maintain the sustainability of the country with the early grades, internalize and moral norms of the nation identity as characteristics the nation of Indonesia which is reflected in the Pancasila, so that it can maintain unity and could face a variety of challenges and threats of disintegration of the nation.

The existence of the Indonesia Homeland region consisting of parts of the Islands, coupled with the diversity of tribal, ethnic, indigenous culture, historical background, as well as religion and belief allows the occurrence of differences of view, way of life, even the difference of goals and objectives. Thus, the unity of the nation of Indonesia or later called national unity is a goal that is quite fundamental to the nation of Indonesia. Therefore, to unite the whole nation of Indonesia diversity requires one basic concept that must be guided by all components of the nation [7]. Pancasila Foundation became the primary to realize the goals and objectives of a national Nation Indonesia, namely 1) protecting all Nations Indonesia and all the spilled blood of Indonesia; 2) advance the general welfare; 3 the intellectual life of the nation); 4) were carrying out a world order based on peace and social justice.

A more detailed view on the relationship between education and ideology can increase our understanding of any potential tensions between the two $[17,18]$. This is the basis of internalization values of Pancasila in citizenship education in an effort to transmit the nation Indonesia characteristics of its citizens. Citizenship education as the education values of Pancasila and as subject-specific pedagogy or instructional material subject to the civic education of teachers at school aims to prepare learners as citizen's country the smart and good. Citizens in question are citizens who master the knowledge, skills, attitudes and values, which are utilized to foster a sense of nationality and love for the Fatherland [19].
In realizing these goals then character development of citizens of Indonesia should be sourced and based on the values of Pancasila in order to reflect the distinctive characteristics of the citizens of Indonesia-Pancasila as part of people of the world. Through internalization of Pancasila values to the next generation a nation of Indonesia expected next generation of the nation could face a range of threats and challenges from the negative influences of globalization. The manifest attempts one through civic education, it is showing that the civic education in core Indonesia is sourced from the values of Pancasila.

\section{CONCLUSION}

Pancasila is the ground state of Indonesia which has the function and position of the view of life as a nation and a country, nation, ideology and the ideological foundations of the open society's main Indonesia in carrying out the life of a nation and a country as part of the world community. The main foundation of Pancasila into in warding off various threats and challenges of globalization that would threaten the existence of the nation. Citizenship education in Indonesia aims to develop citizens who are intelligent and good in nation and character building that stems from the values of Pancasila. It is based on the core construction of a nation must comply with the basic consensus-oriented country, to keep the general agreement to the formation of a nation and the State. It is therefore a core citizenship education in Indonesia is the values of Pancasila which is the result of consensus-forming the nation of Indonesia.

\section{REFERENCES}

[1] Malihah, E. An ideal Indonesian in an increasingly competitive world: Personal character and values required to realise a projected 2045 'Golden Indonesia'. Citizenship, Social and Economic Education, 14 (2): 148-156. 2015.

[2] Noor Syam, M. Filsafat Ilmu. Malang: FKIP UM. 2006.

[3] Dumont, L. Essays on Individualism. Chicago: University of Chicago Press. 1986.

[4] Winataputra, U. S. dan Budimansyah, D. Pendidikan Kewarganegaraan dalam Perspektif Internasional: Konteks, Teori dan Profil Pembelajaran. Bandung: Widja Aksara Press. 2012

[5] Wahab, A. A. Memantapkan Kembali Jatidiri Bangsa dalam Kerangka Penguatan Dasar-Dasar Pendidikan Kewarganegaraan Indonesia. Prosiding Seminar Internasional Pendidikan Kewarganegaraan. Bandung: Laboratorium Pendidikan Kewarganegaraan. 2009.

[6] Miles, M.B. and Huberman, A.M. Analisis Data Kualitatif. Jakarta: UI Press. 1992.

[7] Santosa, K. O. Paradigma Baru Memahami Pancasila dan UUD 1945. Bandung: Sega Arsi. 2005.

[8] Maryanto. Urgensi Pembaharuan Hukum Indonesia Berdasarkan NilaiNilai Pancasila. Jurnal Hukum, 25 (1): 420-438. 2011.

[9] Mansyur, M. A. Aneka Persoalan Hukum. Semarang: Sultan Agung Press. 2006

[10] Maftuh, B. \& Sapriya. Pembelajaran PKn melalui Konsep. Jurnal Civicus, 1 (5): 319-328. 2005.

[11] Amirrachman, R. A. Peace education in the Moluccas, Indonesia: Between global models and local interests. Doctoral Dissertation. Netherlands: University of Amsterdam. 2012.

[12] Holtzappel, C. 'Nationalism and Cultural Identity', in M. Hitchcock and V.T. King (eds) Images of Malay Indonesian Identity. Kuala Lumpur: Oxford University Press. 1997.

[13] Bubandt, N. Democracy, corruption, and the politics of spirit in contemporary Indonesia. Oxon, UK: Routledge. 2014. 
[14] Frederick, William H., and Robert L. W. "Indonesia: A Country Study." In Area Handbook Series. 5th Edition. Washington, D.C.: Federal Research Division for Sale by the Supt. of Docs., U.S. G.P.O. 1993.

[15] Shihab, R. Wawasan Kebangsaan: Menuju NKRI Bersyariah. Jakarta: Suara Islam Press. 2012.

[16] Budiarjo, M. Dasar-Dasar Ilmu Politik. Jakarta: Gramedia Pustaka Utama. 2001.
[17] Hindman, D. B. Mass media flow and differential distribution of politically disputed beliefs: The belief gap hypothesis. Journalism \& Mass Communication Quarterly, 86: 790-808. 2009.

[18] McCright, A. M., \& Dunlap, R. E. The politicization of climate change and polarization in the American public's views of global warming, 2001-2010. The Sociological Quarterly, 52: 155-194. 2011.

[19] Grace et al, 2009 pp. 6. 